\title{
Faktor-Faktor yang Berpengaruh Terhadap Kinerja Usaha Wanita Wirausaha Kerupuk Udang di Provinsi Jambi
}

D 0 I:10.18196/ agr.2232

\begin{abstract}
The purpose of this research is to analyze the relationship of personal characteristics on the entrepreneurial behavior and factors affecting the business performance of prawn crackers women entrepreneurs in Jambi Province. This study was conducted using a survey in two regencies in the Jambi Province. The method of analysis used in the study is Structural Equation Modelling (SEM) with Partial Least Square (PLS) approach. The results shows i) training, business experience, education, and family background positively significant affect to the entrepreneurial behavior (including motivation, innovation and risk taking decision); ii) business performance is influenced by personal characteristics, entrepreneurial behavior, internal environment and the external environment. Per-
\end{abstract}

sonal characteristic of women entrepreneur on prawn crackers business in Jambi Province is the most influence factor on woman business performance. Keywords: business performances, internal and external environment, women entrepreneurs

\section{INTISAR I}

Penelitian ini bertujuan untuk menganalisis hubungan karakteristik personal dengan perilaku kewirausahaan dan menganalisis faktor-faktor yang mempengaruhi kinerja usaha wanita wirausaha kerupuk udang di Provinsi Jambi. Penelitian ini dilakukan dengan metode survey di dua kabupaten di Provinsi Jambi. Metode analisis yang digunakan yaitu Structural Equation Modelling (SEM) dengan pendekatan Partial Least Square (PLS). Hasil penelitian menunjukkan bahwa i) pelatihan, pengalaman bisnis, pendidikan, dan latar belakang keluarga berpengaruh positif terhadap perilaku kewirausahaan (motivasi, inovasi dan berani mengambil risiko); ii) kinerja usaha dipengaruhi oleh karakteristik personal, kewirausahaan, lingkungan internal, dan lingkungan eksternal. Karakteristik personal wanita wirausaha pada pada usaha kerupuk udang di Provinsi Jambi merupakan variabel yang paling penting dalam mempengaruhi kinerja usaha wanita wirausaha.

Kata kunci: kinerja usaha, lingkungan eksternal dan internal, wanita wirausaha

\section{PENDAHULUAN}

Pengembangan sektor usaha mikro kecil dan menengah (UMKM) merupakan salah satu upaya untuk dapat mempercepat pembangunan di suatu negara. Di Indonesia, meningkatnya peran dan kegiatan usaha sektor ini terlihat pada saat Indonesia mengalami krisis ekonomi di tahun 1997. Pada masa tersebut UMKM mampu bertahan dan menunjukkan perkembangan yang pesat dalam membantu perekomian Indonesia ke arah yang lebih stabil. Hal ini sesuai dengan penelitian yang dilakukan oleh Demirbag et. al. (2006) bahwa keberhasilan sektor usaha kecil dan menengah memberikan dampak yang postitif terhadap pembangunan 
ekonomi di negara maju maupun berkembang. Sektor usaha kecil dan menengah akan memiliki kemampuan dalam menciptakan lapangan pekerjaan dengan biaya minimum. Usaha kecil dan menengah dapat menjadi pelopor dalam berinovasi bagi dunia dengan memiliki fleksibilitas tinggi dalam memberikan pelayanan yang terbaik bagi konsumennya.

Jumlah usaha UMKM yang ada di Indonesia terus mengalami peningkatan, pada tahun 2013 berjumlah 56 juta unit usaha, namun tidak semua usaha diperhitungkan sebagai wirausaha. Menurut penilaian Kemenkop jumlah wirausaha di negara ini hanya 1,65\% dari total seluruh penduduk Indonesia sebesar 250 juta jiwa (Sasongko, 2015). Jumlah ini masih lebih rendah dari jumlah wirausaha minimal yang harus ada dalam suatu negara, yakni 2\% dari total penduduk David McClelland (Kemenristek, 2012). Dengan demikian Indonesia masih perlu mendorong penduduknya untuk mengembangkan wirausaha.

Berdasarkan pengelompokan usaha, UMKM pengolahan makanan dan minuman merupakan sektor usaha yang memiliki jumlah terbanyak dari total UMKM, yaitu sebesar 34,94\% (BPS, 2014). Pengolahan makanan dan minuman merupakan produk yang banyak diminati, memiliki daya serap pasar cukup tinggi, dan sampai pada saat ini belum mengalami titik jenuh walaupun pertumbuhannya lambat, hanya sekitar 4\% (Bukhari, 2013). Usaha pengolahan hasil pertanian maupun perikanan berupa produk olahan makanan (pangan) merupakan usaha yang banyak digeluti oleh wanita wirausaha. Menurut Laporan Kementerian Luar Negeri (2010), jumlah wanita wirausaha di Indonesia berada pada urutan ketiga di wilayah Asia Pasifik. Meningkatnya peran dan partisipasi wanita dalam dunia bisnis bukan sebuah fenomena baru, tetapi peran wanita telah terjadi di seluruh dunia (Kumbhar, 2013). Wanita wirausaha merupakan sumber daya manusia (SDM) yang berperan penting bagi suatu negara. Peran wanita ini dapat dijadikan sebagai mediator dalam pertumbuhan ekonomi serta pembangunan ekonomi melalui kegiatan kewirausahaan (Kumbhar, 2013).

Provinsi Jambi merupakan salah satu provinsi di Indonesia yang berada di wilayah Sumatera, yang dikenal sebagai penghasil kerupuk udang. Sentra pembuatan kerupuk udang di Provinsi Jambi berada di Kabupaten Tanjung Jabung Timur dan Kabupaten Tanjung Jabung Barat, dengan produksi perikanan laut (udang dan jenis ikan lainnya) yang cukup tinggi, sebesar 22.346,70 ton/ tahun di Kabupaten Tanjung Jabung Barat dan 26.907,62 ton/tahun di Kabupaten Tanjung Jabung Timur (Dinas Perikanan dan Kelautan Provinsi Jambi, 2015). Sejalan dengan tingginya produksi, jumlah dari wanita wirausaha di kedua kabupaten mengalami peningkatan, dari 60 orang wanita wirausaha pada tahun 2011 menjadi 105 orang pada tahun 2013 (Desprindag kab. Tanjung Jabung Timur dan Barat, 2013). Dengan ketersediaan bahan baku yang cukup, keinginan wanita untuk dapat menambah penghasilan bagi keluarga dan mencari kesibukan lain di luar kegiatan sebagai ibu rumah tangga, serta adanya dukungan pemerintah setempat melalui program wanita wirausaha, motivasi wanita untuk dapat berwirausaha di kedua kabupaten ini menjadi tinggi. Hal ini ditunjukkan dari keterlibatan wanita dalam beberapa program yang telah dilakukan pemerintah, misalnya program pelatihan dan pendampingan. Namun, fakta di lapangan menunjukkan bahwa kegiatan usaha yang ditekuni wanita belum mengalami perkembangan yang signifikan, sehingga perlu dikaji faktor-faktor apa yang mempengaruhi kinerja usaha yang ditekuni wanita. Sementara ini, teknologi yang masih sederhana dan masih kurangnya wilayah pemasaran diduga menjadi faktor yang menyebabkan kinerja usaha wanita wirausaha belum berkembang.

Dalam mengembangkan usaha, wanita wirausaha membutuhkan kemampuan bersaing, kemampuan memanfaatkan teknologi, dan kemampuan berinovasi sehingga dapat meningkatkan kinerja usahanya. Wanita wirausaha pada umumnya masih menggunakan teknologi yang sederhana/manual, mengalami keterbatasan modal, menghadapi pasar yang belum memadai padahal bahan baku tersedia cukup banyak. Di sisi lain, keragaman jenis pelatihan yang diberikan oleh pemerintah tidak diimbangi dengan promosi, sehingga wanita wirausaha sulit untuk dapat memasarkan hasil produksinya. Namun, pengalaman wanita wirausaha yang telah cukup banyak di bidang usaha yang digeluti, dapat menjadi asset yang dimiliki oleh wanita wirausaha. Pengetahuan dan pengalaman dalam menjalankan usaha merupakan peluang besar dalam pengembangan usaha. Melalui pengalaman seseorang dapat belajar banyak hal, karena bila hanya dengan satu pengalaman seorang wirausaha tidak akan sanggup menghadapi, memecahkan permasalahan, dan mencapai peluang yang akan dihadapi (Dirlanudin, 2010). Munizu (2010) melakukan penelitian pengaruh faktor eksternal dan internal terhadap strategi bisnis dan pertumbuhan UMKM. Faktor lingkungan 
eksternal terdiri dari aspek kebijakan pemerintah pada sektor usaha kecil dan menengah, aspek sosial, budaya, dan ekonomi, serta aspek peranan lembaga terkait; sedangkan faktor lingkungan internal terdiri dari aspek keuangan, aspek teknis produksi dan operasi, aspek pasar dan pemasaran, serta kinerja usaha terdiri dari pertumbuhan penjualan, pertumbuhan modal, pertumbuhan pasar, pertumbuhan laba. Dari hasil penelitiannya Munizu (2010) menemukan bahwa: i) karakteristik individu manajer/pemilik, karakteristik usaha, lingkungan eksternal bisnis, dampak kebijakan ekonomi dan sosial memiliki pengaruh langsung secara positif, dan signifikan terhadap strategi bisnis serta pertumbuhan usaha; ii) usaha kecil dan mikro akan tumbuh pada lingkungan usaha dengan aturan/kebijakan mendukung dan informasi yang dapat dipercaya. Kebijakan yang mendukung memungkinkan usaha dapat dikelola dengan baik dan stabil. Sementara informasi yang dapat dipercaya dan mudah diakses akan berdampak pada keberhasilan usaha. Tulisan ini mencoba untuk menguji keterkaitan antara faktor-faktor faktor eksternal dan internal perilaku kewirausahaan dengan kinerja usaha pada usaha kerupuk udang di Provinsi Jambi.

\section{METODE PENELITIAN}

Penelitian ini dilakukan di dua kabupaten di Provinsi Jambi, yaitu di Kabupaten Tanjung Jabung Timur dan Kabupaten Tanjung Jabung Barat, yang merupakan sentra pengolahan kerupuk udang di Provinsi Jambi. Dari dua kabupaten yang dipilih sebagai lokasi penelitian, dipilih Kecamatan Muara Sabak dan Kecamatan Tungkal Ilir. Kegiatan pengumpulan data dalam penelitian dilakukan pada bulan Juni 2015-Agustus 2015.

Jenis data yang digunakan dalam penelitian ini adalah data primer dan sekunder. Sumber data primer diperoleh melalui wawancara langsung dengan wanita wirausaha pemilik usaha, serta penggalian informasi dari petugas pembinaan wanita wirausaha dari Dinas Desperindag setempat, sedangkan data sekunder diperoleh dari Dinas Desperindag, dan Dinas Perikanan dan Kelautan, Dinas Koperasi dan UMKM serta Badan Pusat Statistik. Seluruh wanita wirausaha yang mengusahakan udang di dua kecamatan terpilih, yakni sebanyak 105 orang dijadikan responden.

Data yang diperoleh dalam penelitian ini adalah data kualitatif dan kuantitatif. Data kualitatif dianalisis secara deskriptif, yaitu mendeskriptifkan karakteristik responden; sedangkan data kuantitatif dianalisis menggunakan Equation Modelling (SEM) dengan pendekatan Partial Least Square (PLS). Pendekatan Partial Least Square (PLS) digunakan untuk melihat pengaruh dari variabel laten karakteristik personal, lingkungan internal, lingkungan eksternal, dan perilaku kewirausahaan terhadap kinerja usaha. Metode Structural Equation Modelling (SEM) dengan pendekatan Partial Least Square (PLS) adalah metode analisis yang powerfull karena tidak didasarkan banyak asumsi. Data yang digunakan tidak harus berdistribusi normal; dapat digunakan untuk data dengan skala pengukuran ordinal, interval dan rasio; dan sampel tidak harus besar (Latan dan Ghazali, 2012). Metode analisis ini dapat digunakan untuk permodelan struktural dengan indikator yang bersifat reflektif maupun formatif. Interpretasi hasil analisis data menggunakan PLS-SEM dilakukan berdasarkan dua tahapan model, yaitu dengan melakukan evaluasi model pengukuran dan evaluasi model struktural (Latan dan Ghazali, 2012).

Tujuan analisis SEM dengan pendekatan PLS dipergunakan untuk mengembangkan dan memprediksi teori, sedangkan Structure Equation Model (SEM) yang bersifat kovarian memiliki tujuan mengkonfirmasi dan menguji teori yang tersedia. Selain itu, SEM-PLS dipergunakan untuk menguji variabel laten endogenous atau mengidentifikasi variabel dalam riset jika riset tersebut adalah riset eksploratori atau perluasan dari teori yang ada.

\section{HASIL DAN PEMBAHASAN}

\section{PROFIL RESPONDEN USAHA KERUPUK UDANG}

Usaha mikro kecil (UMK) pangan olahan perikanan kerupuk udang yang terdapat di wilayah Kabupaten Tanjung Jabung Timur dijalankan oleh wanita wirausaha dengan usia lebih tua dibandingkan dengan wanita wirausaha yang ada di Kabupaten Tanjung Jabung Barat. Wanita wirausaha Kabupaten Tanjung Jabung Timur mayoritas berusia di atas 40 tahun (44,83\%); sedangkan di Kabupaten Tanjung Jabung Barat berusia di antara 2630 tahun $(42,55 \%)$. Perbedaan usia ini mengindikasikan terdapatnya perbedaan minat untuk berwirausaha di dua kabupaten tersebut, di Kabupaten Jabung Timur wanita sudah berminat berwirausaha sejak berusia masih muda.

Wanita wirausaha kerupuk udang di Kabupaten Tanjung Jabung Barat memiliki tingkat pendidikan formal lebih tinggi dibandingkan dengan wanita 
wirausaha di Kabupaten Tanjung Jabung Timur. Proporsi wanita wirausaha berpendidikan SMA di Kabupaten Tanjung Jabung Barat lebih tinggi $(53,19 \%)$ dari pada wanita wirausaha di Kabupaten Tanjung Jabung Timur (25,85\%). Lebih tingginya pendidikan formal wanita wirausaha di Kabupaten Tanjung Jabung Barat memungkinkan wirausaha di wilayah tersebut lebih mudah dalam mengadopsi teknologi. Menurut Welter dan Smallbone (2011), pendidikan dan pengetahuan yang memadai dapat membantu seorang wirausaha untuk lebih mudah beradaptasi dengan lingkungannya. Dengan modal pendidikan, wirausaha dapat mengeksploitasi

TABLE I. HASIL PENILAIAN TERHADAP VARIABEL MANIFEST DAN T-VALUE FAKTOR-FAKTOR YANG BERPENGARUH TERHADAP KINERJA USAHA

\begin{tabular}{|c|c|c|c|c|}
\hline Variabel Laten & Variabel indikator & Loading factor & t-value & \\
\hline \multicolumn{5}{|l|}{ Karakterisik Personal (KP) } \\
\hline & Pendidikan (KP.01) & 0,562 & 20,19 & \\
\hline & Latar Belakang Keluarga (KP.02) & 0,771 & 21,67 & \\
\hline & Pengalaman (KP.03) & 0,840 & 29,55 & \\
\hline & Pelatihan (KP.04) & 0,910 & 23,34 & \\
\hline \multicolumn{5}{|l|}{ Lingkungan internal (LI) } \\
\hline \multirow[t]{4}{*}{ Aspek keuangan } & Modal sendiri (LI.01) & 0,863 & 23,31 & \\
\hline & Modal pinjaman (LI.02) & 0,481 & 9,21 & \\
\hline & Tingkat keuntungan dan akumulasi modal (LI.03) & 0,766 & 11,69 & \\
\hline & Membedakan pengeluaran pribadi/keluarga (LI.04) & 0,775 & 17,06 & \\
\hline \multirow[t]{3}{*}{ Aspek teknis dan operasional } & Tersedianya mesin dan peralatan (LI.05) & 0,547 & 8,54 & \\
\hline & Ketersediaan bahan baku (LI.06) & 0,895 & 25,12 & \\
\hline & Kapasitas produksi (LI.07) & 0,649 & 15,41 & \\
\hline \multirow[t]{4}{*}{ Aspek pasar dan pemasaran } & Harga bersaing (LI.08) & 0,743 & 15,86 & \\
\hline & Permintaan pasar (LI.09) & 0,856 & 17,54 & \\
\hline & Kegiatan promosi (LI.10) & 0,561 & 10,32 & \\
\hline & Saluran distribusi dan wilayah pemasaran (LI.11) & 0,605 & 9,45 & \\
\hline \multicolumn{5}{|l|}{ Perilaku Kewirausahaan (PK) } \\
\hline & Risiko (PK.0l) & 0,889 & 30,24 & \\
\hline & Motivasi (PK.02) & 0,921 & 35,94 & \\
\hline & Inovasi (PK.03) & 0,707 & 28,54 & \\
\hline \multicolumn{5}{|l|}{ Kinerja usaha (KU) } \\
\hline & Pertumbuhan modal & 0,682 & 68,09 & \\
\hline & Pendapatan usaha & 0,834 & 19,60 & \\
\hline & Volume penjualan & 0,870 & 22,52 & \\
\hline & Wilayah pemasaran & 0.605 & 8,54 & \\
\hline \multicolumn{5}{|l|}{ Lingkungan eksternal (LE) } \\
\hline \multirow[t]{4}{*}{ Aspek kebijakan pemerintah } & Akses permodalan dan pembiayaan (LE.01) & 0,237 & & 5,22 \\
\hline & Kegiatan pembinaan melalui SKPD (LE.02) & 0,873 & & 53,65 \\
\hline & Peraturan dan regulasi pro bisnis (LE.03) & 0,792 & & 19,35 \\
\hline & Penyiapan lokasi usaha dan informasi (LE.04) & 0,320 & & 14,06 \\
\hline Aspek sosial budaya dan & Tingkat pendapatan masyarakat (LE.05) & 0,832 & & 22,74 \\
\hline \multirow[t]{3}{*}{ ekonomi } & Tersedianya lapangan pekerjaan (LE.06) & 0,628 & & 31,36 \\
\hline & Iklim usaha dan investasi (LE.07) & 0,874 & & 26,34 \\
\hline & Pertumbuhan ekonomi (LE.08) & 0,598 & & 14,06 \\
\hline Aspek peranan lembaga & Akses modal lembaga terkait (LE.09) & 0,036 & & 4,31 \\
\hline \multirow[t]{2}{*}{ terkait } & Monitoring dan evaluasi (LE.10) & 0,788 & & 24,93 \\
\hline & Pendampingan (LE.1l) & 0,770 & & 16,76 \\
\hline \multirow[t]{4}{*}{ Kinerja Usaha (KU) } & Pertumbuhan modal (KU.01) & 0,682 & & 12,43 \\
\hline & Pendapatan (KU.02) & 0,837 & & 44,46 \\
\hline & Volume penjualan (KU.03) & 0,871 & & 39,21 \\
\hline & Wilayah pemasaran (KU.04) & 0,605 & & 13,93 \\
\hline
\end{tabular}




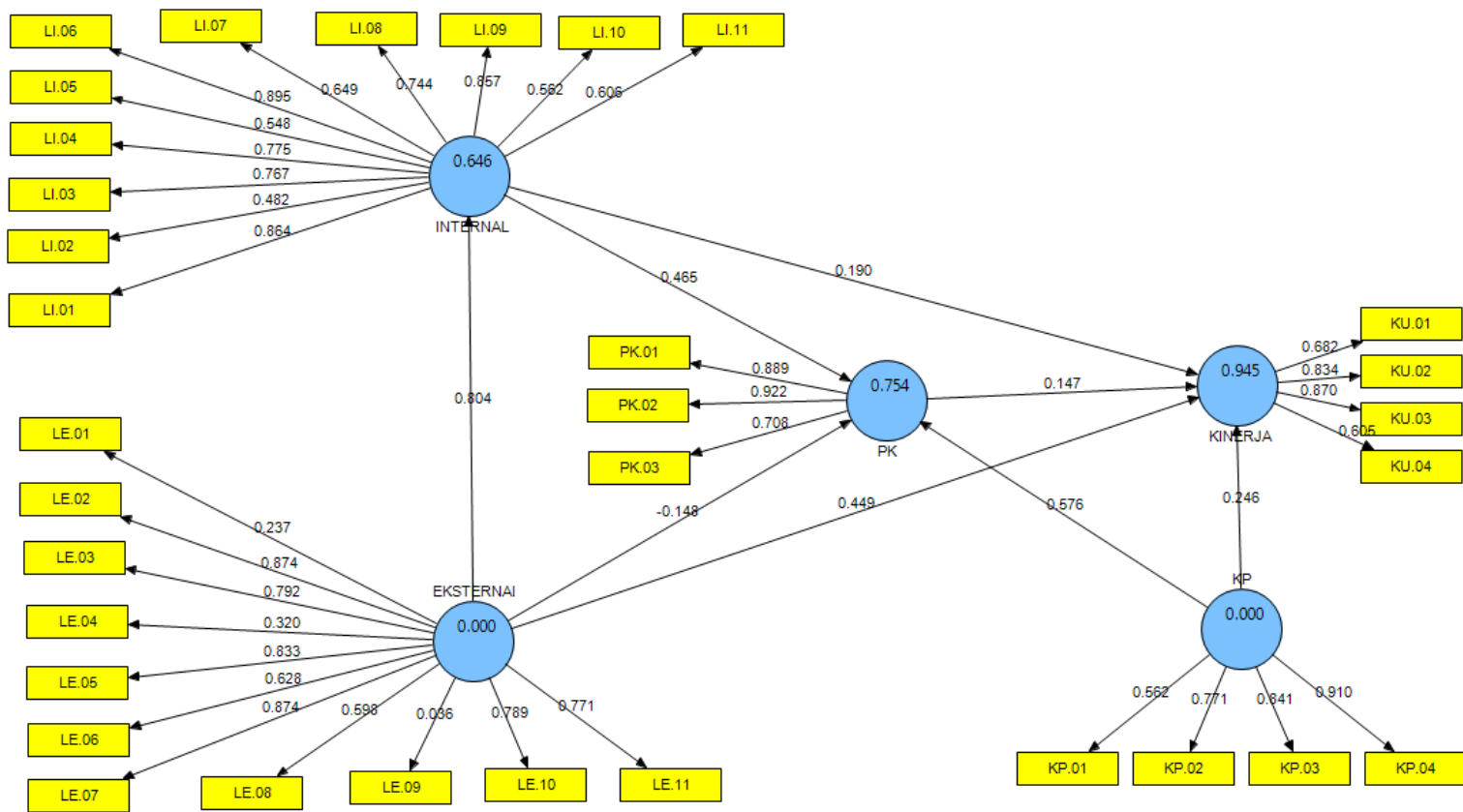

GAMBAR I. TAMPILAN HASIL PLS-SEM ALGORITHM PADA MODEL TAHAP AWAL

peluang, lebih mudah menyesuaikan diri dengan struktur kelembagaan yang berubah-ubah, dan mudah melakukan kontak bisnis dalam membangun jaringan sosial untuk mengatasi hambatan dalam kelembagaan.

Secara keseluruhan jumlah tanggungan keluarga wanita wirausaha antara 4 sampai 8 orang merupakan jumlah tanggungan keluarga yang paling dominan, namun jumlah tanggungan keluarga wanita wirausaha di Kabupaten Tanjung Jabung Timur relatif lebih sedikit dibandingkan di Kabupaten Tanjung Jabung Barat. Di Kabupaten Tanjung Timur didominasi wanita wirausaha dengan jumlah tanggungan kurang dari 4 orang $(41,38 \%)$; sedangkan di Kabupaten Tanjung Jabung Barat didominasi wanita wirausaha dengan jumlah tanggungan 4-8 orang $(73,8 \%)$.

Pengalaman kerja berperan dalam mempengaruhi seorang wanita untuk dapat berwirausaha. Sebagian besar wanita wirausaha belum pernah bekerja, yakni $58,62 \%$ di Kabupaten Tanjung Jabung Timur dan 69,05\% di Kabupaten Tanjung Jabung Barat. Artinya, pengalaman kerja wanita wirausaha di Kabupaten Tanjung Jabung Timur lebih tinggi dibandingkan di Kabupaten Tanjung Jabung Barat. Sejumlah 41,38\% wanita wirausaha di Tanjung Jabung Timur pernah bekerja di sektor swasta, sedangkan di Tanjung Jabung Barat hanya sebesar 28,57\% yang pernah bekerja di sektor swasta, dan 2,38\% lainnya pernah bekerja di sektor pemerintah.

\section{EVALUASI MODEL PENGUKURAN}

Evaluasi model pengukuran (outer model) merupakan tahap untuk memastikan bahwa konstruk yang digunakan pada penelitian ini memenuhi kriteria validitas dan reliabilitas. Model pengukuran PLS-SEM digunakan untuk mengukur hubungan setiap indikator (manifest) dengan variabel latennya. Evaluasi nilai nilai loading factor merupakan langkah pertama yang dilakukan dalam evaluasi model pengukuran. Nilai dari loading factor (ë) yang diperoleh menjadi tolak ukur dalam melakukan penilaian kebaikan dari model, dengan mengeluarkan nilai loading factor yang kurang dari 0,5. Hasil evaluasi model pengukuran yang dapat dilihat pada Gambar 1, menunjukkan bahwa terdapat tiga indikator yang memiliki nilai loading factor kurang dari 0.5 yaitu modal pinjaman (LI.02) dari lingkungan internal; penyiapan lokasi usaha dan informasi (LE.04), akses permodalan dan pembiayaan (LE.01) dari lingkungan eksternal.

Pada evaluasi model pengukuran (measurement model) untuk mengetahui apakah suatu indikator (variabel manifest) yang digunakan dalam penelitian benar-benar dapat mengukur variabel laten atau konstruknya, salah 
satunya yaitu dengan menilai tingkat validitas indikator melalui loading factor (Latan dan Ghazali, 2012). Pada Tabel 1 ini akan ditampilkan hasil penilaian evaluasi model dengan melihat loading factor dan t-value dengan alat bantu software Smart PLS 2.0.

\section{EVALUASI MODEL STRUKUTURAL}

Evaluasi model struktural (inner model) dilakukan setelah dihasilkan model akhir yang telah dianggap valid dan reliabel. Tujuan dari dilakukannya evaluasi model struktural yaitu untuk dapat melihat hubungan antar variabel laten, salah satunya dilakukan dengan melihat dari hasil estimasi koefisien parameter jalur dan tingkat signifikan (Latan dan Ghazali, 2012). Uji signifikansi hubungan antar variabel laten merupakan tahap akhir dalam evaluasi model struktural.

\section{PENGARUH KARAKTERISTIK PERSONAL TERHADAP PERILAKU KEWIRAUSAHAAN}

Hasil analisis PLS-SEM pada model struktural, menunjukkan bahwa masing-masing zona signifikan dibentuk oleh karakteristik ruang, karakteristik usaha, dan karakteristik pelaku usaha. Hal ini karena, nilai tvalue yang diperoleh dari masing-masing karakteristik zona, lebih besar dari 1,96 (Tabel 2).

\section{TABEL 2. KOEFISIEN JALUR DAN T-VALUE}

\begin{tabular}{lll}
\hline Hipotesis & Nilai Koefisien & T-hitung \\
\hline Ling. Eksternal - > Ling. Internal & 0,811 & $36,65^{\circ}$ \\
Ling. Eksternal - > Kinerja Usaha & 0,452 & $8,99^{*}$ \\
Ling. Eksternal - > PK & $-0,161$ & 1,25 \\
Ling. Internal - > Kinerja Usaha & 0,207 & $4,38^{*}$ \\
Lingkungan Internal - > Perilaku & 0,494 & $7,54^{*}$ \\
Kp - $>$ Kinerja Usaha & 0,238 & $3,80^{*}$ \\
KP - > PK & 0,564 & $5,35^{*}$ \\
PK - $>$ Kinerja Usaha & 0,133 & $2,78^{*}$ \\
${ }^{*}(0,05): 1,96$ & & \\
\hline
\end{tabular}

Hasil uji hipotesis pada Tabel 5 menunjukkan bahwa hubungan antar laten yang dibangun memiliki pengaruh yang signifikan pada tingkat kepercayaan 0,05; pada kinerja usaha signifikan dipengaruhi oleh karakteristik personal dengan atributnya pendidikan (KP.01), latar belakang keluarga (KP.02), pengalaman (KP.03), pelatihan (KP.04). Di antara atribut-atribut karakteristik personal tersebut, pelatihan dan pengalaman bisnis merupakan variabel yang dominan mempengaruhi perilaku kewirausahaan. Hal ini dikarenakan kedua atribut tersebut memiliki nilai loading factor paling besar (ë=0,840;0,910).

Dari pengalaman bisnis wanita wirausaha menjalankan kegiatan usaha kerupuk udang ini, rata-rata berkisar antara 5-7 tahun. Dari pengalaman yang cukup ini, wanita wirausaha dapat lebih memahami manajemen dalam menjalankan usaha serta berhati-hati dalam mengambil sebuah keputusan untuk dapat menghidari risiko-risiko dalam usahanya. Ini terlihat dari kualitas kerupuk udang yang dihasilkan oleh wanita wirausaha, sebagai dampak dari pelatihan yang diikuti misalnya memilih udang yang berkualitas, pengendalian pengendalian mutu kerupuk melalui proses produksi sebagai berikut: i) mixing yaitu pencampuran udang, tepung, dan bumbu-bumbu dengan perbandingan 1:1 untuk lebih dapat meningkatkan rasa, kekenyalan dan pengembangan volume adonan; ii) pemotongan menggunakan peralatan pisau dan talenan yang terbut dari kayu, karena wanita wirausaha telah mengetahui tebal tipisnya kerupuk udang yang diproduksi; iii) penebaran kerupuk udang untuk dijemur menggunakan rak-rak dari kayu dan bambu yang dilapisi kawat maupun plastik; iv) pengemasan menggunakan plastik standar SNI untuk menjaga kerupuk agar tahan lebih lama. Akan tetapi hanya sedikit dari wanita wirausaha yang telah menggunakan label IRT. Pelatihan memiliki nilai loading factor yang paling tinggi dalam mempengaruhi perilaku kewirausahaan (inovasi, motivasi dan risiko). Pelatihan yang diikuti oleh wanita wirausaha antara lain "Pelatihan Kewirausahaan Mitra Binaan Usaha Kecil dan Menengah (UKM)" yang dalam kegiatan tersebut wanita wirausaha dilatih dalam: i) pembuatan kerupuk udang; ii) pengendalian mutu; iii) pemilihan kualitas bahan baku yang benar.

Selain itu, latar belakang keluarga memiliki nilai loading factor $(0,771)$ yang menunjukkan bahwa dukungan keluarga untuk menjalankan usaha menyebabkan motivasi wanita wirausaha menjadi tinggi. Hal ini sesuai dengan penelitian Sanputi (2010) yang mengungkapkan dorongan berbentuk motivasi yang kuat untuk maju dari pihak keluarga merupakan modal awal untuk menjadi seorang wirausaha. Selain itu, terdapat sekitar 9\% dari wanita wirausaha menjalankan usaha kerupuk udang ini merupakan turunan dari keluarganya. Di sisi lain, wanita wirausaha memulai usaha untuk meningkatkan pendapatan yang tidak mencukupi untuk menopang kebutuhan keluarganya. Sementara itu, pendidikan merupakan atribut yang paling rendah dari karakteristik personal yang mempengaruhi perilaku kewirausahaan 
dengan $\ddot{e}=0,562$. Ini berarti tingkat pendidikan wanita wirausaha di Kabupaten Tanjung Jabung Barat memiliki tingkat pendidikan SMA dan Kabupaten Tanjung Jabung Timur yaitu tingkat SMP. Artinya dengan pendidikan wanita wirausaha yang cukup tinggi memudahkan dapat penerimaan informasi baru, seperti pada saat pelatihan wanita wirausaha dengan dengan dukungan rata-rata usia 31-35 tahun yang memiliki motivasi tinggi untuk maju dalam usahanya. Menurut Davidson dan Honig (2003) pendidikan akan memberikan pengaruh terhadap pengambilan keputusan seseorang serta mampu untuk membaca peluang yang ada. Melalui jenjang pendidikan yang tinggi, wanita wirausaha memiliki potensi sekaligus peluang lebih besar untuk dapat berkembang.

\section{FAKTOR-FAKTOR YANG MEMPENGARUHI KINERJA USAHA}

Kinerja merupakan hasil atau tingkat pencapaian keberhasilan seseorang secara keseluruhan baik secara kualitas maupun kuantitas sesuai dengan tanggung jawab yang diberikan selama periode tertentu untuk melaksanakan pekerjaan dibandingkan dengan berbagai kemungkinan seperti standar hasil kerja, target atau kriteria yang telah ditentukan (Rivai dan Basri 2005; Mangkunagara 2002). Menurut Praag (2005) keberhasilan kinerja usaha dapat dilihat dari adanya keberlangsungan serta tingkat pertumbuhan usaha itu sendiri, penambahan jumlah tenaga kerja, dan peningkatan keuntungan dan pendapatan usaha.

Pada hasil analisis PLS-SEM pengaruh dari masingmasing variabel indikator terhadap kinerja usaha pada wanita wirausaha kerupuk udang di Provinsi Jambi menunjukkan bahwa lingkungan eksternal, lingungan internal, karakteristik personal, perilaku kewirausahaan berpengaruh signifikan terhadap kinerja usaha pada taraf nyata 0,05 . Hasil analisis data mengenai pengaruh dari variabel indikator terhadap kinerja usaha dapat dilihat pada Tabel 3.

TABEL 3. PENGARUH VARIABEL INDIKATOR TERHADAP KINERJA USAHA

\begin{tabular}{|c|c|c|}
\hline Hipotesis & Nilai Koefisien & T-hitung \\
\hline KP -> Kinerja Usaha & 0,238 & $3,80^{\circ}$ \\
\hline $\begin{array}{l}\text { PK - > Kinerja Usaha } \\
\mathrm{t}(0,05): 1,96\end{array}$ & 0,133 & $2,78^{*}$ \\
\hline
\end{tabular}

Tabel 3 menunjukkan bahwa karakteristik personal berpengaruh positif dan signifikan terhadap kinerja usaha dengan nilai koefisien 0,238 dan nilai thitung
3,80. Nilai koefisien 0,238 ini memberikan pengertian bahwa pada penelitian ini terdapat pengaruh positif karakteristik personal terhadap kinerja usaha, dalam arti peningkatan karakteristik personal akan meningkatkan perilaku kewirausahaan. Ini berarti kinerja usaha wanita wirausaha hanya dipengaruhi oleh karakteristik yang melekat pada dirinya sendiri, seperti pendidikan, pelatihan, pengalaman bisnis dan latar belakang keluarga. Ini dikarenakan selama ini wirausaha wanita selain mengandalkan kemampuan yang ada pada dirinya sendiri, wanita wirausaha juga memanfaatkan informasi yang diperoleh dari pelatihan yang diikutinya. Hal ini sejalan dengan pendapat Dalimunthe (2002) bahwa karakteristik personal akan mempengaruhi pengambilan keputusan dan tindakan yang sangat erat kaitannya dengan peningkatan kinerja usaha.

Perilaku kewirausahaan pada Tabel 3 berpengaruh positif dan signifikan terhadap kinerja usaha dengan nilai koefisien 0,133 dan nilai thitung 2,78. Perilaku kewirausahaan pada penelitian ini dilihat dari inovasi, motivasi dan keberanian mengambil risiko. Hal ini berarti kinerja usaha juga dicerminkan dari perilaku kewirausahaan wanita wirausaha. Pada perilaku kewirausahaan, motivasi $(\ddot{\mathrm{e}}=0,921)$ merupakan faktor yang dominan dan kuat dalam mempengaruhi kinerja usaha. Dalam kondisi ketersediaan bahan baku yang tinggi, sedangkan wilayah pemasaran terbata di lingkungan usaha atau di Kota Jambi, tidak membuat motivasi untuk berwirausaha menjadi rendah. Wanita wirausaha kerupuk udang justru tekun dan mempunyai semangat agar usaha yang dijalankannya dapat bertahan. Selanjutnya, perilaku kewirausahaan juga dicerminkan oleh indicator keberanian mengambil risiko $(\ddot{e}=0,889)$ yang memiliki nilai loading factor tinggi. Umumnya risiko yang dihadapi oleh wanita wirausaha dalam menjalankan usahanya ini tergolong rendah. Harga kerupuk udang yang cenderung stabil, ketersediaan bahan baku yang kontinyu, serta barang yang tidak cepat rusak memungkinkan wanita wirausaha meminimalkan risiko. Hal ini juga dibuktikan dengan inovasi produk yang dilakukan seperti membuat kerupuk udang dalam bentuk stick yang siap makan. Hal ini sesuai dengan hasil penelitian Noersasongko (2005) yang mengungkapkan bahwa motivasi, inovasi, dan risiko merupakan faktor yang dianggap memiliki pengaruh dominan terhadap keberhasilan usaha, adanya motivasi yang tinggi akan meningkatkan kinerja usaha. Selain itu juga, pendapatan yang diperoleh dari usahanya mengalami peningkatan dari tahun ke tahun yang 
diimbangi dengan peningkatan volume penjualan. Meskipun jika dilihat pendapatan yang diperoleh wanita wirausaha dari menjalankan usaha masih tergolong rendah yaitu Rp1 juta - Rp1.5 juta, namun pendapatan tersebut menambah dana untuk memenuhi kebutuhan hidup sehari-hari dibandingkan jika tidak memiliki usaha ini.

\section{PENGARUH LINGKUNGAN EKSTERNAL DAN INTERNAL TERHADAP KINERJA USAHA}

Lingkungan usaha merupakan dinamika pergerakan lingkungan bisnis yang mempengaruhi kinerja usaha, yang terdiri dari lingkungan internal (mikro) dan lingkungan ekonomi yang merupakan lingkungan eksternal (makro). Analisis lingkungan adalah suatu proses monitoring terhadap lingkungan organisasi yang bertujuan untuk mengidentifikasi peluang (opportunities) serta tantangan (threats) yang akan mempengaruhi kemampuan sebuah perusahaan untuk mencapai tujuan perusahaan (Dirgantoro, 2001). Hasil analisis data pengaruh dari lingkungan eksternal dan internal terhadap kinerja usaha dapat dilihat pada Tabel 4 .

\section{TABEL 4. HASIL PENGARUH LINGKUNGAN USAHA TERHADAP KINERJA USAHA}

\begin{tabular}{lll}
\hline Hipotesis & Nilai Koefisien & T-hitung \\
\hline Ling. Eksternal - > Kineria Usaha & 0,452 & $8,99^{*}$ \\
Ling. Internal - > Kineria Usaha & 0,207 & $4,38^{*}$ \\
\hline${ }^{*}(0,05): 1,96$ & & \\
\hline
\end{tabular}

Tabel 4 menunjukkan bahwa lingkungan eksternal berpengaruh positif dan signifikan terhadap kinerja usaha dengan nilai t-hitung sebesar 8,99. Ini berarti lingkungan eksternal yang terdiri dari aspek kebijakan pemerintah, aspek sosial budaya dan ekonomi dan aspek peranan lembaga terkait mampu meningkatkan kinerja usaha. Pada aspek kebijakan pemerintah yang memiliki nilai loading factor cukup tinggi yaitu kegiatan pembinaan melalui SKPD (ë=0.873), kegiatan pembinaan yang dilakukan oleh pemerintah daerah cukup terbilang rutin yaitu dalam setahun dilakukan beberapa kali. Pembinaan dilakukan oleh beberapa dinas antara lain Dinas Perikanan dan Kelautan dan Dinas Perindag. Banyaknya dinas yang memberikan pembinaan membuat wanita wirausaha mempunyai wadah untuk mengkonsultasikan permasalahan yang dihadapinya seputar kegiatan usaha. Peraturan dan regulasi pro bisnis dengan nilai loading factor cukup tinggi $(\ddot{e}=0,792)$ mengindikasikan pemerintah berperan serta dalam peraturan yang pro bisnis yang memberikan kesempatan kepada wanita wirausaha untuk dapat mengembangkan pengetahuannya melalui pembinaan dari instansi terkait. Akan tetapi dalam hal penyediaan lokasi dan informasi $(\ddot{e}=0,320)$ serta akses permodalan dan pembiayaan $(\ddot{e}=0,237)$ masih dirasakan kurang, ini terlihat dari nilai loading factor yang dibawah 0,5. Dari hasil observasi di lapangan, penyiapan lokasi usaha dilakukan oleh wanita wirausaha sendiri yang ratarata lokasi usaha sama dengan tempat tinggal; hanya sebagian kecil dari wanita wirausaha yang membedakan lokasi usaha dengan kediamannya. Sementara itu, akses permodalan dan pembiayaan masih dirasakan sulit, karena dinas setempat hanya memberikan pembinaan. Wanita wirausaha yang membutuhkan pinjaman modal harus membuat proposal terlebih dahulu yang dianggap wanita wirausaha sangat sulit. Selain itu, banyak persyaratan untuk meminjam modal dari instansi tertentu dan membutuhkan proses yang cukup lama.

Selain aspek kebijakan pemerintah, aspek sosial budaya dan ekonomi juga merupakan bagian dari lingkungan eksternal. Terkait dengan aspek sosial budaya dan ekonomi, tingkat pendapatan masyarakat (ë=0,832), iklim usaha dan investasi $(\ddot{e}=0,874)$ adalah faktor yang paling dominan mempengaruhi kinerja usaha. Melalui usahanya, sebagian dari masyarakat yang ada di sekitar tempat usaha dipekerjakan sebagai tenaga kerja walaupun masih dalam kapasitas yang rendah (ë=0,628). Pada umumnya wanita wirausaha mempekerjakan $1-2$ orang masyarakat di sekitar untuk membantu dalam kegiatan produksi. Jumlah volume penjualan yang meningkat dan terjadinya peningkatan pendapatan dari modal awal mengindikasikan iklim usaha kerupuk udang cukup menjanjikan. Selain itu juga, terdapat aspek peranan lembaga terkait (ë=0,036), seperti peran perbankan yang masih kurang, karena untuk meminjam dana dari bank wanita wirausaha harus memiliki masa umur usaha tertentu, sehingga hanya beberapa dari wanita wirausaha yang memperolehnya. Akan tetapi monitoring dan evaluasi $(\ddot{e}=0,788)$, serta pendampingan $(\ddot{e}=0,770)$ berpengaruh cukup baik, artinya ada pengawasan dari pihak bank terkait yang bekerja sama dengan pemerintah daerah dalam hal pengontrolan wanita wirausaha yang memperoleh dana pinjaman. Hal ini sama seperti yang dikemukakan oleh Abimbola dan Agboola (2011) bahwa lingkungan usaha meliputi faktor seperti infrastruktur, budaya, ekonomi, sosial, dan lingkungan politik 
(lingkungan eksternal) terbukti dapat menghambat ataupun memfasilitasi kegiatan kewirausahaan dalam masyarakat manapun.

Lingkungan internal pada Tabel 4 berpengaruh positif dan signifikan terhadap kinerja usaha dengan nilai thitung 4,38. Lingkungan internal terdapat aspek keuangan, yaitu modal sendiri $(\ddot{e}=0,863)$ merupakan modal awal wanita wirausaha mendirikan usahanya, ratarata modal awal dikelurkan wanita wirausaha masih rendah yaitu Rp500 ribu- Rp1 juta sehingga dengan modal yang masih kecil ini maka perkembangan usahanya menjadi lamban. Sedangkan untuk tingkat keuntungan dan akumulasi modal $(\ddot{e}=0,766)$, artinya wanita wirausaha berusaha untuk dapat mengakumulasikan keuntungan yang diperoleh untuk modal usaha berikutnya, tetapi dari hasil penelitan apabila ada kebutuhan yang mendesak untuk keluarga, maka wanita wirausaha akan menggunakan modal usahanya untuk kepentingan tersebut. Wanita wirausaha di Provinsi Jambi ini telah mampu untuk membedakan pengeluaran pribadi/keluarga $(\ddot{e}=0,775)$ artinya wanita wirausaha belajar untuk dapat melakukan pencatatan arus kas masuk dan keluar dari usahanya untuk dapat memudahkan pemisahan antara kebutuhan pribadi maupun usaha sehingga usaha dapat berlanjut. Pada aspek teknis dan operasional, ketersediaan bahan baku (ë=0,895) memiliki nilai loading yang tinggi, jika dilihat dari kondisi/lokasi yang berada di pesisir pantai dan banyaknya nelayan yang melaut sehingga ketersediaan bahan baku tidak menghawatirkan bagi wanita wirausaha untuk keberlanjutan usahanya terutama harga udang yang masih rendah antara Rp5.000-Rp15.000 per kilogramnya. Akan tetapi permasalahan utama pada aspek teknis dan operasional terletak pada tersedianya mesin dan peralatan $(\ddot{e}=0,547)$ yang masih rendah karena wanita wirausaha memanfaatkan teknologi yang masih sederhana, yang akan berakibat pada kapasitas produksi yang masih rendah. Walaupun sebagian dari wanita wirausaha telah mendapatkan bantuan mesin peralatan, tetapi mereka enggan menggunakannya karena mengakibatkan bertambahnya biaya listrik maupun gas (apabila menggunakan oven pengering kerupuk). Selanjutnya jika dilihat dari aspek pasar dan pemasaran pada harga bersaing ( $\ddot{e}=0,743)$ dimana masing-masing dari wanita wirausaha menerapkan harga sesuai dengan keinginan mereka, yaitu Rp50.000. Harga kerupuk udang wanita wirausaha di Jambi ini tergolong tinggi, jika dibandingkan dengan kerupuk udang di daerah lain. Hal ini dikarenakan campuran antara tepung dan udang di Jambi 1:1 sedangkan di daerah lain 3:1. Inilah yang mendasari mengapa harga kerupuk udang di Jambi lebih mahal karena wanita wirausaha usaha menganggap bahwa kualitas produksi yang mereka hasilkan berbeda. Jika dilihat dari sisi permintaan pasar (ë=0,856), permintaan kerupuk udang cukup tinggi walaupun wilayah pemasaran $(\ddot{e}=0,605)$ kerupuk udang yang masih terbatas. Hal ini tidak menyebabkan wanita wirausaha menghadapi permasalahan, karena berapapun hasil produksi yang mereka buat selalu terserap pasar. Jika dilihat dari kegiatan promosi $(\ddot{e}=0,561)$ masih rendah, promosi dilakukan hanya dari mulut ke mulut, eventevent yang dilakukan oleh pemerintah daerah masih terbatas hanya beberapa kali dalam setahun. Munizu (2010) menyatakan bahwa faktor-faktor internal yang terdiri dari atas sumber daya manusia, aspek keuangan, aspek teknis produksi atau operasional, dan aspek pasar dan pemasaran berpengaruh positif dan signifikan terhadap kinerja usaha. Sementara itu, faktor lingkungan eksternal yang terdiri dari aspek kebijakan pemerintah, aspek sosial budaya dan ekonomi, dan aspek peranan lembaga terkait mempunyai pengaruh yang signifikan dan positif terhadap faktor-faktor internal. Ini mengindikasikan bahwa lingkungan eksternal mempengaruhi kondisi internal di dalam sebuah usaha atau bisnis yang dijalankan wirausaha.

\section{KESIMPULAN}

Karakteristik personal yaitu pendidikan, latar belakang keluarga, pengalaman bisnis dan pelatihan berpengaruh positif terhadap perilaku kewirausahaan (motivasi, inovasi dan berani mengambil risiko). Sementara perilaku kewirausahaan dan karakteristik personal berpengaruh terhadap kinerja usaha. Motivasi wanita wirausaha merupakan indikator perilaku kewirausahaan yang memiliki pengaruh paling kuat, sementara pelatihan yang diikuti wanita wirausaha merupakan indikator karakteristik personal yang memiliki pengaruh paling kuat.

Lingkungan eksternal dan internal berpengaruh positif dan signifikan terhadap kinerja usaha. Lingkungan internal yang paling dominan mempengaruhi kinerja usaha adalah ketersediaan bahan baku, sedangkan lingkungan eksternal yang paling dominan mempengaruhi kinerja usaha adalah kegiatan pembinaan melalui SKPD. 
Berdasarkan hasil penelitian yang telah dilaksanakan, diperlukan adanya dukungan dari pemerintah untuk meningkatkan kinerja usaha melalui peningkatan kapasitas produksi, yakni kemudahan untuk mendapatkan teknologi yang tepat untuk membantu bagian produksi, kemudahan untuk mendapat label usaha sehingga kerupuk yang diproduksi dapat dikenali oleh konsumen, serta akses permodalan melalui kerjasama dengan pihan bank. Disamping itu, Untuk dapat meningkatkan keberhasilan usaha, diperlukan adanya suatu tempat penampungan hasil produksi kerupuk udang, sehingga akses pemasaran kerupuk tidak menjadi sulit dan dapat bersaing dengan kerupuk udang yang berasal dari daerah lain.

\section{DAFTAR PUSTAKA}

Abimbola, O. H., \& Agboola, G. M. 2011. Environmental factors and entrepreneurship development in Nigeria. Journal of Sustainable Development in Africa 13(4).

Bukhari, A. 2013. Industri makanan dan minuman salah satu penopang pertumbuhan. Media Industri, 40.

Dalimunthe, R. 2002. Pengaruh Karakteristik Individu, Kewirausahaan, Gaya Kepemimpinan terhadap Kemampuan Usaha serta Keberhasilan Usaha Industri Kecil Tenun dan Bordir di Sumatra Utara, Sumatra Barat dan Riau. Disertasi, Universitas Airlangga.

Davidsonn, P., \& Honig, B. 2003. The role of social and human capital among nascent entrepreneurs. Journal of Business Venturing 18: 301-331.

Dinas Perikanan dan Kelautan Provinsi Jambi. 2015. Jumlah Hasil Perikanan dan Kelautan Provinsi Jambi 2014. Pemerintahan Kabupaten Tanjung Jabung Timur dan Kabupaten Tanjung Jabung Barat, Jambi.

Dirgantoro, C. 2001. Manajemen Stratejik: Konsep, Kasus, dan Implementasi. PT. Gramedia Widiasarana Indonesia, Jakarta.

Dirlanudin. 2010. Perilaku Wirausaha dan Keberdayaan Pengusaha Kecil Industri Agro: Kasus di Kabupaten Serang Provinsi Banten. Disertasi, Institut Pertanian Bogor.

Demirbag, M., Tatoglu, E., Tekinkus, \& Zaim, S. 2006. An analysis of the relationship between TQM implementation and organizational performance: evidence from Turkish SMEs. Journal of Manufacturing Technology Management 17(6): 829-847.

Dinas Perindustrian dan Perdagangan Kabupaten Tanjung Jabung Barat. 2013. Jumlah Unit Usaha, Industri Kecil dan Kerajinan Rumah Tangga Kabupaten Tanjung Jabung Barat. Disperindag-Kabupaten Tanjung Jabung Barat, Jambi.

Dinas Perindustrian dan Perdagangan Kabupaten Tanjung Jabung Timur. 2013. Jumlah Unit Usaha, Industri Kecil dan Kerajinan Rumah Tangga Kabupaten Tanjung Jabung Timur. Disperindag-Kabupaten Tanjung Jabung Timur, Jambi.

Kementrian Riset dan Teknologi. 2012. Startup entrepreneurship (Online). Diakses 05 Desember 2015. http://www.ristek.go.id

Kementrian Luar Negri Republik Indonesia. 2010. Pengembangan Kewirausahaan Perempuan Menghadapi Komunitas Ekonomi ASEAN 2015 (Online). Diakses 05 Desember 2015. http:// www.kemlu.go.id

Kumbhar, V. 2013. Some critical issues of women entrepreneurship in
Rural India. European Academic Research 1(1):5

Latan, H, \& Ghazali, I. 2012. Partial Least Square Konsep, Teknik dan Aplikasi Menggunakan Smartpls 2.0 M3. Badan Penerbit Universitas Diponegoro, Semarang.

Munizu, M. 2010. Pengaruh faktor-faktor eksternal dan internal terhadap kinerja usaha mikro dan kecil (UMK) di Sulawesi Selatan. Jurnal Manajemen dan Kewirausahaan 12(1): 33-41.

Noersasongko, E. 2005. Analisis Pengaruh Karakteristik Individu, Kewirausahaan, dan Gaya Kepemimpinan terhadap Kemampuan Usaha serta Keberhasilan Usaha pada Usaha Kecil Batik di Jawa Tengah. Disertasi, Universitas Merdeka Malang.

Praag, C. M. 2005. Succesessful Entrepreneurship.Edward Elgar Publishing Limited, United Kingdom.

Rivai, V., \& Basri, A. F. 2005. Performance Appraisal: Sistem yang Tepat untuk Menilai Kinerja Karyawan dan Meningkatkan Daya Saing Perusahaan. PT Raja Grafindo Persada, Jakarta.

Sanputi, S. 2010. Analisis faktor-faktor yang memotivasi wanita berwirausaha (studi pada pengusaha salon kecantikan pada Kecamatan Medan Tembung). Jurnal Keuangan dan Bisnis 2(3): 258.

Sasongko, A. 2015. Jumlah pengusaha Indonesia hanya 1,65 persen (Online). Diakses Agustus 2015. http://nasional.republika.co.id/ berita/nasional/umum/15/08/13/nl3 i58-jumlah-pengusahaindonesia-hanya-165-persen 